\title{
Taxonomic revision of Leopold and Rudolf Blaschka Glass Models of Invertebrates 1888 Catalogue, with correction of authorities
}

\author{
Running title: Taxonomic Revision of 1888 Blaschka Catalogue
}

Eric Callaghan ${ }^{1}$, Bernhard Egger ${ }^{2}$, Hazel Doyle ${ }^{1}$, and Emmanuel G. Reynaud ${ }^{1 \#}$

\section{Affiliations:}

1. School of Biomolecular and Biomedical Science, University College Dublin, Ireland.

2. Institute of Zoology, University of Innsbruck, Austria

\# Correspondence should be addressed to:

Conway Institute

School of Biomolecular and Biomedical Science

University College Dublin,

Belfield, Dublin 4, Ireland.

Tel.: + 35317166750

Email: emmanuel.reynaud@ucd.ie

ORCID: 0000-0003-1502-661X

Keywords: Invertebrate, Blaschka, museum, collection, taxonomy 


\begin{abstract}
The glass models of invertebrates crafted by Leopold and Rudolf Blaschka were made between 1863 and 1889. Production ceased when the glassmakers turned their attention to what is now known as the Ware Collection of Blaschka Glass Models of Plants, created for the Harvard Museum of Natural History. Nearly 130 years have passed since their last published catalogue of species in 1888 and the nomenclature they applied is now a confusing mix that includes many junior synonyms and unavailable names. This is an issue for many museums and universities which owns Blaschka models as uncertain identifications may compromised interpretation of this rediscovered legacy. Nowadays, many museums and universities hold collections of those glass invertebrates but misspelled, mislabelled or simply apply the century old taxonomy of 1888 . Here, we provide a valuable resource for curators and enthusiasts alike. We studied and updated the final catalogue 1888 from the Blaschkas' Dresden-based workshop. We first focused on major taxonomical changes from taxa to species, as well as on an analysis of the acknowledged authorities. We found that only $35.3 \%$ of the models retain their original names, while 3.7\% lack any known synonym and their identity remains open to interpretation. Finally, two of the authorities listed in the catalogue, Ernst Haeckel and Philip Henry Gosse, were incorrectly acknowledged for an extensive range of models. This study is the first of its kind on the Blaschka collection, and it will help in the identification and naming of Blaschka models worldwide.
\end{abstract}




\section{INTRODUCTION}

During the 18th century, the Swedish botanist Carl von Linné (Carolus Linnaeus) established a "two-term naming system", also known as the binomial nomenclature to name every specie. This system is now governed by international codes of rules such as the International Code of Zoological Nomenclature (ICZN). This system encompasses terrestrial as well as marine species that became the focus of many expeditions in the 19th century. The reports on these explorations, from François Auguste Péron's jellyfish drawings (Péron, 1816) to Ernst Haeckel's radiolarian engravings (Haeckel, 1887), alongside the massive 35 volumes from the HMS Challenger expedition reports (1872-1876), opened a new world to the masses, enabling them to see these creatures both in books and in prints, but also in museums and exhibitions. This museum movement, designed to educate the people and to display what the world has to offer, could easily be advanced by the display of skeletons and exotic stuffed animals, but the marine world, other than fishes and dolphins, remained difficult to display.

One workshop, based in the German town of Dresden, found a solution to the challenge of displaying the newly described marine invertebrates, which usually faded, or shrank in preservatives. The glassblowers Leopold and Rudolf Blaschka, father and son, used their knowledge of glass and its translucent qualities, as well as pigments to create artificial jellyfishes and other soft-bodied invertebrates that could be exhibited easily (Reiling; 1998 and 2000). However, they relied on books, lithographs, and sometimes live creatures kept in tanks to produce their models (Dohrn A.; 1877). Many different books and monographs were used as source illustrations such as Philip Henry Gosse's Actinologia Britannica: A History of the British Sea-Anemones and Corals (Gosse, 1860), Haeckel's Das System der Medusen (Haeckel, 1879) or Jean Baptiste Vérany’s Céphalopodes de la Méditerranée (Vérany, 1851). The Blaschkas created more than 700 models that were sold worldwide through their own workshop and also through three dealers: Robert Damon (United Kingdom and Ireland), Václav Frič (Austria and Hungary), and Henry Augustus Ward (North America). These models are quality representations, and they are often referred to as masterpieces in which their art matches their true biological nature (Sheets-Pyenson, 1988; Dyer, 2008).

Since the production of these magnificent models ended in 1889 , a wealth of marine biological data has accumulated, and there have been many taxonomic changes. In addition, challenges to established ideas and concepts have led to the extensive reorganization of the 
Tree of Life (e.g., the Archean Kingdom). However, the name "glass models of invertebrates," which has been consistently applied to the Blaschkas' creations, has never been challenged, presumably because these models were extremely accurate, and little has been published about their taxonomy. Although some work has been done on the origin of their designs and their sources of inspiration, it is often very general and incomplete.

We decided to investigate the taxonomy of the Blaschkas' 700-plus glass models of invertebrates listed in the two English catalogues $(1878 ; 1888)$ published by Ward's Natural Science Establishment from archives such as those housed in the Rakow Research Library of The Corning Museum of Glass (which contains the archives the Blaschkas' workshop), as well as the large, digitized holdings of the online Biodiversity Heritage Library (BHL) and World Register of Marine Species (WoRMS). We also analyzed the authority for each species and the taxonomic value of the original species' name versus the currently established one. We thus established a new version of the Blaschkas' catalogue with the correct modern taxonomy and authority for each species, along with a unique set of "Blaschka species" that exist only as glass models (the species they described are no longer considered valid). Finally, we uncovered a bias toward using the work of the British naturalist Philip Henry Gosse and Ernst Haeckel as recognized authorities. 


\section{MATERIAL AND METHODS}

\section{Archival Material}

The two original catalogues that describe the glass invertebrate models sold by the Blaschkas' workshop in Dresden were obtained from the following sources: Ward's Natural Science Establishment catalogue (1878): Reese Library of the University of California. (online access: https://babel.hathitrust.org/); Ward's Natural Science Establishment catalogue (1888): River Campus Libraries, University of Rochester, Rochester, New York, Henry Augustus Ward Papers (1840-1933), reference A.W23.

Analysis of Data

Because of the extent of the species and phyla covered by the Leopold and Rudolf Blaschka, we had to work, for the most part, on well-established and curated online databases to ascertain the validity of the models. All the model specie names were checked, and the taxonomy - from phylum to species - was updated as much as possible.

The principal databases consulted were: World Register of Marine Species (WoRMS), www.marinespecies.org; Marine Species Identification Portal, speciesidentification.org; and the Catalogue of Life, www.catalogueoflife.org.

We also used the Biodiversity Heritage Library, www.biodiversitylibrary.org. This is a source of scanned original books that also contains chromolithographies and help us to compare with Blashcka drawings and the final modeland confirm or infirm the binomial nomenclature.

We always rely on the provided information from those databases. Depending on the final established taxonomy, we used the following provided taxonomical naming: "nomen dubium" (Latin, "doubtful name," indicating that the taxonomic validity is uncertain or disputed by various experts), "nomen nudum" (Latin, "naked name," indicating a name that has been published without an adequate description), and "species inquirenda" (Latin, "species of doubtful identity, requiring further investigation"). In cases where no matching entry could be found in any of these databases, an online search was conducted to crossreference other sources, which often clarified the identification or suggested a possible alternative. For several models, no current identification could be found, despite our best 
bioRxiv preprint doi: https://doi.org/10.1101/408260; this version posted September 6, 2018. The copyright holder for this preprint (which was not certified by peer review) is the author/funder, who has granted bioRxiv a license to display the preprint in perpetuity. It is made available under aCC-BY-NC-ND 4.0 International license.

efforts. These models are then designated as "ND" (No Data) in the updated version of the catalogue. 


\section{RESULTS}

\section{General Catalogue Analysis}

There are two catalogues of the models produced by the Blaschka workshop, which were made available to us from different archives. In 1878, Henry Augustus Ward published a catalogue specifically for the Blaschkas' invertebrate models, probably based on a German edition of the glassmakers' workshop catalogue, in which the models are listed according to the generally accepted invertebrate taxonomy (Ward, 1878). Each model was assigned a unique catalogue number ( 1 to 630 ) that would become a standard reference. For ease of reference the models in this article, are ordered according to these numbers as these are consistent and reliable identifiers. Because this catalogue was produced in the United States of America, the models are priced in dollars and cents.

In 1888, Ward printed a revised catalogue to include the models that had been added by the Blaschkas since the publication of his 1878 catalogue, but new additions (631 to $704+$ 6 non-numbered models) to this new catalogue were rather listed at the end. This means that many phyla have models appearing in two sections in the numbered list; once in Models 1630 and again amongst 631-704. The first 630 models show a traditional textbook systematic arrangement for numbers $1-630$ as per Ward 1878. Numbers 630-713 are models subsequently added to the repertoire in later catalogues and show a similar systematic ordering although with sponges added last.

The Blaschkas were glassblowers, not taxonomists, and they had to rely on the limited taxonomic literature available at the time and especially chromolithographies within them that allows them to produce coloured models. The most well-known example is the anemones based lithograpies illustrated P.-H. Gosse book (e.g. Caryophilla Smithii). Henry Ward was a geologist. At that time, it was customary to assign a specific status to organisms based on minor differences that would today be regarded as a subspecies at best, and therefore some of the models in the catalogues represent "species" that are no longer considered valid. In addition, it is possible that some of the species were incorrectly identified in the first place.

None of the two catalogues follow the established taxonomic conventions, in that the generic and specific names are not italicized. Also, species names were capitalized when they refer to persons which was common practice in the literature of the time (e.g., Model no. 30, Actinoloba Paumotensis, and Model no. 43, Bunodes Ballii). 
There are many spelling errors throughout the catalogues. . These may have been the fault of the printers, who would not have been experts in the field (e.g., model no. 20 is listed as Actinaria rather than Actiniaria). These mistakes may indicate that neither Ward nor the Blaschkas corrected their manuscripts before they were printed.

\section{Analyzing Ward's 1888 Catalogue}

We used Henry Ward's 1888 catalogue as the last available catalogue to establish a reference of the complete Blaschka marine invertebrate collection. Seven hundred four models are perfectly numbered, and there are six models at the end of the catalogue that have no numbers, establishing 713 as the complete set of models offered to customers. However, the distribution is highly variable across phyla, classes, and orders (Table 1). Moreover, there are minor discrepancies in the catalogue. Model 141 (Cladonema radiatum) is listed twice (development and adult), but there is only one associated number because the model of the adult is not numbered separately. The same situation applies for Model 191 (Tubularia indivisa). Also, in addition to the model numbered 219 (Rhizophysa Eysenhardti, there is a model 219a (Rhizophysa heliantha, now Anthorhybia rosacea).

Of the 713 models, $19(2.6 \%)$ are of varieties no longer considered valid, although three of these are now regarded as full species in their own right; 10 (1.4\%) represent developmental stages of species (note that models 252 and 669 have no adult forms listed in the catalogue); $12(1.7 \%)$ illustrate the anatomy of species, three of which are not otherwise included in the catalogue; and four $(0.6 \%)$ represent male and female specimens of two species. Therefore, the 713 models represent 694 species as recognized at that time.

General Changes in Taxonomy (from the 1888 Ward Catalogue)

At the phylum level, three phyla are still valid (Echinodermata, Mollusca, and Porifera) and two phyla (Coelenterata and Vermes) are obsolete, while Tunicata is now a subphylum of Chordata. The Protozoa, introduced in 1818 as a taxonomic class, has been and remains a problematic area of taxonomy but is currently considered a subkingdom in the kingdom Protista. Coelenterata now encompasses the current phyla Ctenophora (comb jellies) and Cnidaria. Platyhelminthes and Annelida are now two phyla that cover the obsolete Vermes phylum. (In the catalogues, the term "Phylum" does not appear; instead, the now obsolete "Type" is found.) 
At the Class level, eight classes are still correct (Anthozoa, Crinoidea, Asteroidea, Holothuroidea, Gastropoda (originally Gasteropoda), Cephalopoda, Thaliacea, and Turbellaria), and one is obsolete (Gephyrea). However, because of the reorganization of phyla and subphyla, many classes are now assigned to various phyla and subphyla (e.g., Anthozoa is now a class of the phylum Cnidaria) (Table 2). Three classes used name that can be commonly found with different spellings: Hydromedusae (Hydroidomedusae, now accepted as Hydroidolina), Gasteropoda (Gastropoda), and Tethyodea (Tethioidea). This could be based on the original book used for the specie name or eventually some printing errors or transcription.

At the Order level, there have been extensive changes, as noted in Table 2. Three orders are now obsolete (Calycozoa, Hydroidea, and Acalephae), while many orders are now regarded as classes, infraclasses, subclasses, or families. Only two orders remain valid today (Zoantharia and Siphonophorae).

Concerning the Species taxonomic classification of the Blaschka marine invertebrate models, $240(33.7 \%)$ are unchanged, $400(56.1 \%)$ have changed (this includes the variations that are no longer recognized), and 40 (5.6\%) have been only tentatively identified. For 25 $(3.5 \%)$, no data can be located (this includes one model that bears the name of a plant species). Finally, four (0.56\%) are described as "nomen dubium," two (0.28\%) are termed "nomen nudum," and two (0.28\%) are regarded as "species inquirenda."

Interestingly, 60 models (8.4\% of the catalogue) are of species that had been described within the preceding 30 years (i.e., since 1858), and 17 of those $(2.4 \%$ of the catalogue) had been described within the preceding 20 years (i.e., since 1868).

\section{Authority}

In taxonomic nomenclature, it is common practice to identify a species using the established binomial name, followed by the "authority." It is a way of identifying the person who first published the name, and it is a very important component of the species' nomenclature. We identified 136 naming authorities, but 22 of these accounted for 64 percent of the names. They include such well-recognized naturalists as Carl von Linné and Jean-Baptiste Lamarck, but also some authors who are regarded as experts in specific branches of invertebrate studies: Louis Agassiz and Edward Forbes (Cnidaria), Jacques Philippe Raymond Draparnaud (Gastropoda), and Otto Friedrich Müller (Actiniaria). 
Philip Henry Gosse, the English naturalist and popular nature writer, is the principal naming authority quoted, with 59 species in the catalogue attributed to him. However, the identification of 50 of these species has been revised. Twelve were reassigned to species already described by Gosse, and 38 were reclassified as species previously identified by other authorities. Only nine were retained as genuinely new species described by Gosse.

Another frequently quoted authority is Ernst Haeckel. Twenty-one species are attributed to Haeckel in the catalogue, 13 of which have been reidentified (four as species previously described by Haeckel, and nine as species previously identified by other authorities). The remaining eight are unchanged as genuinely new species described by Haeckel.

\section{DISCUSSION}

The Blaschka workshop, based in Dresden, developed a unique series of marine invertebrate models between 1863 and 1890, using as reference zoological illustrations such as those contained in Gosse's Actinologia Britannica or Ludwig Schmarda's Neue wirbellose Thiere (1859-1861). Although the current focus by many museums and universities on Blaschka models is welcome for highlighting invertebrate biology, interpretation of this rediscovered legacy is compromised by uncertain identifications. With the passing of time and new expeditions and discoveries, the extent of knowledge of the biological world increased, as did the complexity of the Tree of Life and the taxonomic keys required to identify every single species.

Because the Blaschkas' models have always been regarded as accurate representations of invertebrates, we investigated the taxonomy of their entire production (713 models) to understand the zoological accuracy of their workshop and the development in understanding of those species over the last 127 years (1888-2015). We established the modern taxonomy of as many models as possible to provide every Blaschka collection curator with a reference table (Table 3) to properly label models with accurate taxonomic identification. But this table will not be the final one because we still have a series of models for which only limited information can be located. Forty models (5.6\%) have been only tentatively identified (Table 4), no data can be located for 25 others (3.5\%) (Table 4), four $(0.56 \%)$ are described as "nomen dubium," two (0.28\%) are termed "nomen nudum," and two (0.28\%) are "species inquirenda" (Table 5). These will require further research.

It is interesting to note that, of the 630 models presented in the 1878 Ward catalogue and the 713 in Ward's 1888 edition, we can identify only 694 species. Because of the 
invalidation of 25 variations of some species and the paucity of firm data on other species referred to in the preceding paragraph, we could finally retrieve only 621 valid and fully identified species, with $400(64 \%)$ being unchanged since the catalogue of 1888 . The Blaschkas' workshop produced a series of models of developmental stages for some species (for example, Model no. 225, Aurelia aurita) and dissections illustrating the internal anatomy of others (for example, Model no. 275, Holothuria tubulosa). In each case, these models are listed in the catalogues under separate numbers, accounting for some of the apparent discrepancies between the number of models listed and the number of species they represent. There are more individual models than the catalogue numbering system implies because, in the species where the developmental stages have been produced, these are presented as a series of models grouped together in one display and listed under a single number.

Environmental conditions can exert a significant influence on the physical appearance of some species. In the past, it was common practice to describe and name animals and plants exhibiting these effects as distinct varieties within a species - a practice that is no longer considered valid. For example, model nos. 122, Caryophyllia Smithii var. clara, and 123, var. castanea, are no longer separated, but are listed as Caryophyllia Smithii.

One particularly interesting part of our findings is related to the naming authorities cited. In taxonomy, a species name is always linked to the name of the person who originally named it and the year when this occurred. Philip Henry Gosse had always been an important influence on the Blaschkas, father and son, as a well-established marine invertebrate expert, even though he was not a zoologist but rather a naturalist and popularizer of natural science. We have noted that the Blaschkas wrongly attributed many species (38 out of 59) to him. We have identified a similar situation with regard to another great influence on the workshop: Ernst Haeckel. We looked in detail at Actinologia Britannica, one of the major books known to have been used by the two glassworkers, and we found that the identification of the authority is often confusing for non-experts and may have been the source of the mistaken identities. In some instances, the Blaschkas listed Gosse himself as the naming authority, but Gosse did not list the actual naming authorities in his illustrations. Wherever a species can be clearly identified, we have retrieved the correct authority (Table 3).

Our work represents an important step toward establishing a complete descriptive database of the Blaschkas' glass invertebrate models, enabling us to identify models and their names in accordance with both the original documents and current taxonomic knowledge. We have already performed several curations of European collections and corrected identification errors that were usually related to the loss of original labels or the mixing of 
those labels during curation, repair, or display. We expect that our Table 3 will be updated because more taxonomists will be able to access the relevant taxonomic information to confirm or correct the identification of the models, and to allow for the taxonomic identification of models for which we have no data (Table 5).

We will continue to use the information gathered during our research to link every model to the original documentation and lithograph used, alongside the drawings held at the Rakow Research Library of The Corning Museum of Glass. We believe that, although the Blaschkas' invertebrate models are often described as unique art pieces, they were originally zoological specimens that need to be curated taxonomically and clearly identified and labeled, even if the species are no longer recognized. We hope that our work will help the Blaschka-related community to curate their collections in a taxonomically correct manner. 
bioRxiv preprint doi: https://doi.org/10.1101/408260; this version posted September 6, 2018. The copyright holder for this preprint (which was not certified by peer review) is the author/funder, who has granted bioRxiv a license to display the preprint in perpetuity. It is made available under aCC-BY-NC-ND 4.0 International license.

\section{ACKNOWLEDGEMENTS.}

We wish to thank the following for their help with this project: Nigel Monaghan and Paolo Viscardi at National Museum Ireland - Natural History. 


\section{SECOND SUMMARY}

Les modèles en verre d'invertébrés de Léopold et Rudolf Blaschka ont été fabriqués entre 1863 et 1889. Leur production a cessé lorsque ses deux maitres verriers ont tourné leur attention sur ce qu'on appelle désormais la collection Ware des modèles de plantes en verre, créés pour le Musée d'histoire naturelle de Harvard. Près de 130 ans se sont écoulés depuis leur dernier catalogue d'espèces d'invertébrés publié en 1888, et de nombreux événements se sont produits dans le monde de la biologie et de la taxonomie des invertébrés. De nos jours, de nombreux musées et universités possèdent des collections d'invertébrés Blaschka en verre, mais souvent mal orthographiés, mal étiquetés ou appliquant simplement la taxonomie centenaire de 1888. Nous fournissons ici une ressource précieuse pour les conservateurs et les passionnés. Nous avons étudié et mis à jour le catalogue final de 1888 de l'atelier de Blaschkas à Dresde. Nous nous sommes d'abord concentrés sur les changements taxonomiques majeurs des taxons aux espèces, ainsi que sur une analyse des autorités reconnues. Nous avons constaté que seulement 35,3\% des modèles ont conservé leurs noms d'origine, tandis que 3,7\% semblent avoir disparu. Enfin, deux des autorités énumérées dans le catalogue, Ernst Haeckel et Philip Henry Gosse, ont été mal attribués pour une vaste gamme de modèles. Cette étude est la première de son genre sur la collection Blaschka, et elle aidera à identifier et nommer les modèles Blaschka dans le monde entier. 


\section{REFERENCES}

Gosse, P. H. (1860) Actinologia Britannica: A History of the British Sea-Anemones and Corals. London (UK), Van Voost.

Haeckel E. (1879). Das System der Medusen. Erster Teil einer Monographie der Medusen. Jena (Germany), Gustav Fischer. available online at http://www.biodiversitylibrary.org/

Haeckel E. (1887). Report on the Radiolaria Collected by H.M.S. Challenger During the Years 1873-1876, Vol. XVIII. London, Eyre \& Spottiswoode. Available online at: http://www.gutenberg.org/files/44527/44527-h/44527-h.htm

Péron M. F. (1816). Voyage de découvertes aux terres australes : exécuté par ordre de Sa Majesté l'empereur et roi, sur les corvettes le Géographe, le Naturaliste, et la goëlette le Casuarina, pendent les années 1800, 1801, 1802, 1803 et 1804 Arthus Bertrand, Paris (France). doi.org/10.5962/bhl.title.44096

Reiling H., (1998). The Blaschkas' Glass Animal Models: Origins of Design. Journal of Glass Studies, 40, 105-126.

Reiling H. (2000). The Blaschkas' Glass Animal Models: Illustrations of 19th Century Zoology. Scientiarum Historia, 26, nos. 1/2, 131-143.

Callaghan E., Doyle H.J., and Reynaud E.G. (2014). The Blaschka Collection at University College Dublin: Rebuilding Its History. Journal of the History of Collections, 26, no. 1, 2014, $63-71$.

Sheets-Pyenson S. (1988). Cathedrals of Science: The Development of Colonial Natural History Museums during the Late Nineteenth Century, Kingston, Ontario: McGill-Queen's University Press.

Dyer R. (2008) Learning through Glass: The Blaschka Marine Models in North American Post Secondary Education, Historical Biology, v. 20, no. 1, pp. 29-37.

Ward H. (1878) Ward's Natural Science Establishment catalogue. Reese Library of the University of California. (online access: https://babel.hathitrust.org/)

Ward H. (1888) Ward's Natural Science Establishment catalogue. River Campus Libraries, University of Rochester, Rochester, New York, Henry Augustus Ward Papers (1840-1933), Reference A.W23. 
Dohrn Anton, Archives Stazione Zoologica, March and November 1877.

Ponder \& Lindberg, Taxonomy of the Gastropoda, 1997.

\section{Weblinks}

A. http://www.animalbase.uni-

goettingen.de/zooweb/servlet/AnimalBase/home/speciestaxon?id=15639 


\section{FIGURE LEGENDS}

TABLE 1- Taxonomic Distribution of Invertebrate Models in Henry Ward's 1888 Catalogue

TABLE 2 Corrected Taxonomic Distribution at the Class and Order Levels of Marine Invertebrate Models in the 1888 Ward Catalogue

TABLE 3 Complete Corrected Taxonomic Naming and Authority of Marine Invertebrate Models in Ward's 1888 Catalogue

[?]: Identification that may require confirmation pending further investigation; Species inquirenda: species the taxonomic validity of which is uncertain or disputed by different experts; Nomen nudum: has not been published with an adequate description; Nomen dubium: a name of uncertain taxonomic significance; Morpha: Taxon below the species level, that has no taxonomic status; it consists of specimens in a population that differ in morphology from other group(s) of specimens in the same population; MSIP Marine Species Identification Portal; WoRMS World Register of Marine Species; ND No Data

TABLE 4 - Species with uncertain or tentative identifications

TABLE 5 - Species with No Identification Information 


\section{TABLES}

\section{TABLE 1}

\begin{tabular}{|c|c|c|}
\hline Phylum & Class & Order \\
\hline \multirow[t]{7}{*}{ Coelenterata (265) } & Antozoa (130) & Alcyonaria (18) \\
\hline & & Zoantharia (107) \\
\hline & & Calycozoa (3) \\
\hline & Hydromedusae (117) & Hydroidea (71) \\
\hline & & Siphonophorae (27) \\
\hline & & Acalephae (17) \\
\hline & Ctenophora (8) & \\
\hline \multirow[t]{3}{*}{ Echinodermata (48) } & Crinoidea (3) & \\
\hline & Asteroidea (10) & Ophiuridae (10) \\
\hline & Holothuroidea (33) & \\
\hline \multirow[t]{4}{*}{ Mollusca (278) } & Gasteropoda (219) & Opisthobranchia (141) \\
\hline & & Prosobranchia (2) \\
\hline & & Pulmonata (45) \\
\hline & Cephalopoda (50) & \\
\hline \multirow[t]{2}{*}{ Vermes (57) } & Platyhelminthes (29) & Turbellaria (29) \\
\hline & $\begin{array}{l}\text { Gephyrea (3) } \\
\text { Annelida (32) }\end{array}$ & \\
\hline \multirow[t]{2}{*}{ Tunicata (33) } & Tethyodea (23) & \\
\hline & Thaliacea (10) & \\
\hline \multirow[t]{3}{*}{ Protozoa (16) } & Rhizopoda (16) & Protoplasta (3) \\
\hline & & Heliozoa (3) \\
\hline & & Radiolaria (10) \\
\hline \multirow[t]{3}{*}{ Porifera (5) } & Calurea & Leucosolenida (1) \\
\hline & Hexactinellida & Lychniscosida (2) \\
\hline & & Hexactinosida (2) \\
\hline
\end{tabular}




\section{TABLE 2}

\begin{tabular}{|c|c|c|}
\hline Class & Current Status/Rank & Comments \\
\hline Anthozoa & Class & Class in Phylum Cnidaria \\
\hline $\begin{array}{l}\text { Hydromedusae } \\
\text { (Hydroidomedusae) }\end{array}$ & Class (Hydroidolina) & Subclass of Hydrozoa, phylum Cnidaria \\
\hline Crinoidea & Class & Class in Subphylum Crinozoa, phylum Echinodermata \\
\hline Asteroidea & Class & Class in Subphylum Asterozoa, phylum Echinodermata \\
\hline Holothuroidea & Class & Class in Subphylum Echinozoa, phylum Echinodermata \\
\hline Gasteropoda & Class (Gastropoda) & Class in Phylum Mollusca \\
\hline Cephalopoda & Class & Class in Phylum Mollusca \\
\hline Gephyrea & Obsolete & \\
\hline $\begin{array}{l}\text { Tethyodea } \\
\text { (Tethioidea) }\end{array}$ & Division & Division of Subphylum Tunicata \\
\hline Thaliacea & Class & Class of Subphylum Tunicata \\
\hline Turbellaria & Class & Class in Phylum Platyhelminthes \\
\hline Alcyonaria & Subclass (Octocorallia) & Subclass of Anthozoa \\
\hline Zoantharia & Order & Order of Subclass Hexacorallia, class Anthozoa \\
\hline Calycozoa & Obsolete & \\
\hline Hydroidea & Obsolete & \\
\hline Siphonophorae & Order & Order of Class Hydrozoa \\
\hline Acalephae & Obsolete & \\
\hline Ophiuridae & Family & Family of Order Ophiurida \\
\hline Opisthobranchia & Infraclass & Infraclass of Class Gastropoda \\
\hline Prosobranchia & Subclass & $\begin{array}{l}\text { Infraclass of Class Gastropoda (Prosobranchia is no longer } \\
\text { accepted as a valid subclass see Ponder \& Lindberg, 1997) }\end{array}$ \\
\hline Pulmonata & Infraclass & Infraclass of Subclass Heterobranchia \\
\hline Turbellaria & Class & Class in Phylum Platyhelminthes \\
\hline
\end{tabular}


bioRxiv preprint doi: https://doi.org/10.1101/408260; this version posted September 6, 2018. The copyright holder for this preprint (which was not certified by peer review) is the author/funder, who has granted bioRxiv a license to display the preprint in perpetuity. It is made available under aCC-BY-NC-ND 4.0 International license.

\section{TABLE 3}

Complete Corrected Taxonomic Naming and Authority of Marine Invertebrate Models in Ward's 1888 Catalogue

[This is currently a separate document] 
bioRxiv preprint doi: https://doi.org/10.1101/408260; this version posted September 6, 2018. The copyright holder for this preprint (which was not certified by peer review) is the author/funder, who has granted bioRxiv a license to display the preprint in perpetuity. It is made available under aCC-BY-NC-ND 4.0 International license.

\section{TABLE 4}

\begin{tabular}{|c|c|c|c|c|c|}
\hline No. & Original Species & Original Authority & Potential Identification & Potential Authority & Year \\
\hline 3 & Alcyonium stellatum & Milne Edwards & Sarcophyton stellatum & Kükenthal & 1910 \\
\hline 6 & Gorgonia verrucosa & Pallas & Eunicella verrucosa & ND & 1766 \\
\hline 21 & Actinia concentrica & Risso & Actinia cari & Delle Chiaje & 1822 \\
\hline 30 & Actinoloba Paumotensis & (Couthouy) Dana & Heteractis crispa & Hemprich \& Ehrenberg in Ehrenberg & 1834 \\
\hline 71 & Paractis erythrosoma & Ehrenberg & Entacmaea quadricolor & Ruppell and Leukart & 1828 \\
\hline 99 & Sagartia rosea & Gosse & Sagartia elegans & Dalyell & 1848 \\
\hline 100 & Sagartia rubus & Drayton & Nemactis rubas & Drayton in Dana & 1846 \\
\hline 112 & Tealia gemma & Drayton & Actinia gemma & Drayton in Dana & 1846 \\
\hline 120 & Balanophyllia italica & Michelin & Balanophyllia europaea & Risso & 1826 \\
\hline 135 & Aequorea violacea & Milne-Edwards & Distichopona violacea & Pallas & 1766 \\
\hline 145 & Clytia aeronautica & Forbes & Phialella quadrata & ND & 1848 \\
\hline 169 & Oceania phosphorica & (Péron) Agassiz & Olindias phosphorica & Delle Chiaje & 1848 \\
\hline 181 & Stomobrachium octocostatum & Sars & Melicertum octostatum & ND & 1835 \\
\hline 182 & Stomotoca dinema & (Forbes) Agassiz & Amphinema dinema & Péron \& Lesueur & 1810 \\
\hline 185 & Tiara conica & (Quoy \& Gaymard) Agassiz & Pandea conica & Quoy \& Gainard & 1827 \\
\hline 197 & Zygodactyla vitrina & Gosse & Aequorea vitrina & ND & 1853 \\
\hline 210 & Physalia Caravella & Eschscholtz & Caravella maxima & Haeckel & \\
\hline 237 & Polyclonia frondosa & (Pallas) Agassiz & Cassiopea frondosa & Pallas & 1774 \\
\hline 251 & Comatula Novae Guineae & Müller & Phanogenia novaeguineae & ND & 1841 \\
\hline 260 & Ophiothrix serrata & Kuhl \& Hasselt & Ophiomastus serratus & Mortensen & 1936 \\
\hline 265 & Chiridota purpurea & Lesson & Trochodota purpurea & Pawson & 1969 \\
\hline 279 & Sporadipus impatiens & (c) Semper & Holothuria (Thymiosycia) impatiens & Forsskål & 1775 \\
\hline 312 & Proceros clavicornis & Schmarda & Pseudoceros clavicornis & ND & 1859 \\
\hline 313 & Proceros cornutus & Müller & Eurylepta cornuta & ND & 1776 \\
\hline 314 & Proceros latissimus & Schmarda & Pseudoceros latissimus type A & ND & 1859 \\
\hline 315 & Proceros viridis & Schmarda & Pseudobiceros viridis & ND & 1859 \\
\hline 330 & Pontobdella vittata & Chamisso & Calliobdella lophii & von Benden \& Hesse & 1863 \\
\hline 335 & Hesione Schmardae & Quatrefages & Myriocyclum schmardae & Grube & 1880 \\
\hline 469 & Placobranchus gracilis & Pease & Thuridilla gracilis & Risbec & 1928 \\
\hline 483 & Trevelyana cristata & Bergh & Nembrotha cristata & ND & 1877 \\
\hline 484 & Trevelyana nigerrima & Bergh & Nembrotha cristata & ND & 1877 \\
\hline 500 & Syphonota punctata & Pease & Aplysia punctata & Cuvier & 1803 \\
\hline 517 & Clausilia bidens & Draparnaud & Papillifera papillaris & Müller & 1774 \\
\hline 539 & Philomycus carolinensis & Binney & Philomycus carolinianus & Bosc & 1802 \\
\hline 561 & Loligo Bianconii & Vérany & Onchyoteuthis banksii & Leach & 1817 \\
\hline 562 & Loligo Meneghini & Vérany & Teleoteuthis meneghini & ND & 1851 \\
\hline 618 & Phallusia pustulosa & Alder & Ascidiella aspersa & Müller & 1776 \\
\hline 619 & Phallusia callosa & Stimpson & Ascidia callosa & Stimpson & 1852 \\
\hline 643 & Eucecryphalus schultzei & Haeckel & Lampromitra schultzei & ND & 1862 \\
\hline 655 & Actinoloba senile & de Blainville & Metridium senile & Linnaeus & 1761 \\
\hline
\end{tabular}


bioRxiv preprint doi: https://doi.org/10.1101/408260; this version posted September 6, 2018. The copyright holder for this preprint (which was not certified by peer review) is the author/funder, who has granted bioRxiv a license to display the preprint in perpetuity. It is made available under aCC-BY-NC-ND 4.0 International license.

\section{TABLE 5}

\begin{tabular}{|c|c|c|}
\hline No. & Original Species Name & Authority \\
\hline 12 & Renilla violacea & Quoy \& Gaimard \\
\hline 15 & Sympodium purpurascens & Ehrenberg \\
\hline 60 & Edwardsia vestita & Forbes \\
\hline 70 & Paractis adhaerens & Ehrenberg \\
\hline 72 & Paractis olivacea & Ehrenberg \\
\hline 87 & Saccanthus purpurascens & Milne Edwards \\
\hline 148 & Cunina campanulata & Eschscholtz \\
\hline 160 & Liriope appendiculata & Forbes \\
\hline 168 & Obelia sphaerulina & Péron \\
\hline 175 & Polyxenia Alderii & Forbes \\
\hline 176 & Rhegmatodes (Aequorea) Forbesianus & Gosse \\
\hline 190 & Trachynema ciliatum & Gegenbaur \\
\hline 194 & Turris neglecta & Forbes \\
\hline 196 & Zygodactyla crassa & Agassiz \\
\hline 198 & Abyla pentagona & Eschscholtz \\
\hline 199 & Agalma rigidum & Haeckel \\
\hline 207 & Halistemma punctatum & Kolliker \\
\hline 209 & Hippopodius gleba & Leuckart \\
\hline 211 & Physalia pelagica & Eschscholtz \\
\hline 233 & Holigocladodes lunulatus & Pennant \\
\hline 368 & Aeolis militaris & Alder \& Hancock \\
\hline 392 & Cratena longibursa & Bergh \\
\hline 442 & Facellina Drummondii & Thompson \\
\hline 697 & Paludina achatina & Sowb \\
\hline & Actinia chiococca & Cocks \\
\hline
\end{tabular}

